|| ISSN(online): 2589-8698 || ISSN(print): 2589-868X || International Journal of Medical and Biomedical Studies

Available Online at www.ijmbs.info

PubMed (National Library of Medicine ID: 101738825)

Index Copernicus Value 2017: 40.03

Volume 3, Issue 3; March: 2019; Page No.158-165

\title{
A CLINICAL STUDY OF KATAKA CHURNA ON MALE SEXUAL DYSFUNCTION \& POOR VISION.
}

\author{
Dr. Shri Ram Saini ${ }^{1}$, Dr. Dholaram Saini ${ }^{2}$ \\ ${ }^{1}$ M.D. Scholar, Roga Evam Vikriti Vigyana National Institution of Ayurveda, Jaipur, Rajasthan, India \\ ${ }^{2}$ Assistant Professor, Samhita Department, Shri Shirdi Sai Baba Ayurvedic College \& Hospital Renwal, \\ Jaipur, Rajasthan, India
}

Article Info: Received 27 February 2019; Accepted 25 March. 2019

Cite this article as: Saini, Dr. S. R., \& Saini, Dr. D. R. (2019). A CLINICAL STUDY OF KATAKA CHURNA ON MALE SEXUAL DYSFUNCTION \& POOR VISION. International Journal of Medical and Biomedical Studies, 3(3).

DOI: https://doi.org/10.32553/ijmbs.v3i3.118

Address for Correspondence: Dr. Shri Ram Saini, M.D. Scholar, Roga Evam Vikriti Vigyana National Institution of Ayurveda, Jaipur, Rajasthan, India

Conflict of interest: No conflict of interest.

\section{Abstract}

Context: Excessive sexual activity or masturbation causes oxidative stress, damaging the inner layer of the eye where the rods and cones are located. Think of rods and cones as molecular strainers that catch light. Oxidative stress of ocular tissues is a major culprit behind vision problems, such as eye floaters, glaucoma and cataracts.

Aim: To evaluate the efficacy of Kataka churna in the management of Male sexual dysfunction and Poor vision.

Methodology: 50 patients who have Timira (Poor vision) with associated symptoms Male sexual dysfunction (MSD) had selected for randomised control trial based on inclusion \& exclusion criteria.

Results: The trial drug Kataka churna showed statistically significant results in subjective parameters of poor vision (Timira roga) but insignificant in MSD.

Key words: Timira, MSD, Kataka churna

\section{Introduction:}

Eyesight is the God's greatest gift to humankind, the blessing that allows us to see our surrounding and feel the exquisite beauty of God's creation. Life without eyesight is miserable and valueless. Hence, it is very important to protect vision at any cost.

Normal vision is being able to see a certain size line on the eye chart [the Snellen chart] from 6 meters away; a normal eye has a near point of $25 \mathrm{~cm}$ to clear vision.

Acharya Sushruta classified the diseases of eye, according to the site of lesion. One group of eye diseases, known as 'DrishtigataRoga' are responsible for visual impairment, both partial and complete.

Drishti: The word Drishti has used in two different meanings in Ayurvedic classics.

\section{Drishti in anatomical sense:}

- Drishtim = Mandala $($ Part of Netra) .

Size of drishtimandala is $1 / 7$ part of krishnamandala ${ }^{i}$.

- Drishtikleda = Lubricating fluid of the eyeball ${ }^{\mathrm{ii}}$

Drishti in physiological sense: 
- Drishtikrishth = Dimness of vision Kshudhavegadharanatiii.

- Drishtihanana $=$ Loss of vision.

If Adhimantha is not treated properly leads to this condition (prognosis of adhimantha). ${ }^{\text {iv }}$

- Drishtivisha = Some immortal Snakes eg. Vasuki has poison in its vision".

Timira comes under the group of DrishtigataRoga. Sushruta considers Timira, Kacha and Linganasha as the progressive clinical stages of the disease Linganasha ${ }^{\text {vi }}$.Many of the clinical features described for Timira are having similarities with the refractive errors.

Aacharya Sushruta described Atimaithun (excessive sexual activity), is an etiological factor causing Netraroga. ${ }^{\text {vii }}$ Aacharya Sushruta not described separate etiological factors of Drishtiroga, there for all the etiological factors of Netraroga also causing Dristi-gataroga.

Need of study:-According to study, excessive sexual activity or masturbation causes oxidative stress, damaging the inner layer of the eye where the rods and cones are located. Think of rods and cones as molecular strainers that catch light. When the strainer become damaged due to oxidative stress, or a deficiency in CGMP, nitric oxide or acetylcholine, the rod visual sensory nerves experience a depletion of C3G phytochemicals, which stabilizes visual input. C3G phytochemicals allow the eye to process images, like a graphics card in a computer. When C3G phytochemicals see a reduction, the eye cannot process images fast enough. The blurry, squiggly lines known as eye floaters are the result of reduced C3G chemicals trying to process images.

Men who ejaculate multiple times a day experience deficiencies in these neuro-chemicals necessary for health eyes and sexual function. Per recent studies, a correlation of eye floaters and sexual dysfunctions, e.g., weak erections, premature ejaculations and impotence, were found. Research has further shown that oxidative stress damages the sympathetic nerves and smooth muscles of the iris. Oxidative stress of ocular tissues is a major culprit behind vision problems, such as eye floaters, glaucoma and cataracts. In fact, Western Europe scientist found almost half of individuals with inflammation involving the posterior segment of the eye had visual impairment. The inflammatory response was often triggered by infection, systemic and metabolic disorders, such as sexual exhaustion. [1] [3] [4][5] [6]viii Patient having sexual dysfunction generally takes sex inducing drugs like sildenafil and tildenafil which cause many side effects include blurred vision and changes in colour vision, abnormal ejaculation, and prolonged erections including abnormal vision, change in colour vision and blurred vision. However, in ayurveda drugs used for the same do not cause side effects like sildenafil and tildenafil.

The enzyme that Viagra-like drugs inhibit is found primarily in two places in the body, the erectile tissue of the penis and the retina of eye, that's why the FDA encourages people to stop taking drugs like Viagra, and call a doctor right away if you experience sudden loss of vision. According to our classics, texts drug theses works on spermatogenesis also addition works on enhancing both immunity and vision.

Considering the above factors and drawbacks, hindrances of the modern system of medicine an effort has been done to find the treatment therefore it is necessary to find a effective treatment.

\section{Aims \& Objectives:}

To evaluate the efficacy of Kataka Churna in the management of Male sexual dysfunction \& Poor vision.

\section{Methodology:}

The study conducted under a strict protocol to prevent bias to reduce the sources of error in the study. This study conducted under the following steps-

1. Selection of patients

2. General observation 


\section{Administration of drug}

The patients for the clinical study were selected from O.P.D. and I.P.D. of NIA Arogyashala Hospital,Roga Nidāna Evam Vikrti Vijñāna and Shalakya department. Selection carried out based on relevant history, signs, symptoms and laboratory investigations suggestive for the disease Timira (refractive errors). An annexed part of Performa those incorporated with the diagnostic criteria of Timira (refractive errors) with the associated complaints of Male sexual dysfunction (MSD).50 patients of Timira (refractive errors) with the associated complaints of Male sexual dysfunction (MSD) registered for the clinical study.

A written in formation and consent form has been given to the selected patients. The patients explained about the purpose, procedures and possible side effects of the trial drugs.

Table 1: Drugs:

\begin{tabular}{|l|l|l|l|l|}
\hline S.N. & Drug & Latin Name & $\begin{array}{l}\text { Part } \\
\text { used }\end{array}$ & Form \\
\hline 1. & Kataka & $\begin{array}{l}\text { Strychnos } \\
\text { potatorum }\end{array}$ & Seed & Churna \\
\hline
\end{tabular}

Dose: Kataka churna in dose of 3gm BD with lukewarm water

Duration of Trial: 2 months

Follow up $15^{\text {th }}, 30^{\text {th }}, 45$ th and $60^{\text {th }}$ days,

Non-drug follows up at the interval of one month for the period of 3 months.

Criteria for the selection of the patient:
A. Inclusion-criteria:

a. Male patients, presents with the complaints of low vision.

b. Patients with classical features of Timira mentioned under the methods of collection of data included.

c. Age between $20-50$ years.

B. Exclusion-criteria

a. Female patients.

b. Age-related eye diseases- as macular degeneration and cataracts.

c. Patient suffered from major illness and trauma.

d. Patient suffered Eye diseases like Glaucoma, Corneal Ulcers and Trachoma.

e. Patient have suffering High B.P., Cardiac diseases, AIDS and Diabetes.

Withdrawal Criteria: -During the course of the clinical trial, that patients who cannot follow the given instructions, they were withdrawn from trial.

\section{Assessment Criteria:}

Subjective Parameters: Patients selected for relief symptoms like- Avyakta Rupa Darshan/ Duram na pashyate (Indistinct distance vision), Vihwala Darshana (Blurred vision) and Makshikadi abhuta dravya darshan (Floaters), Dwidha/ Bahuvidha darshan(Diplopia/Polypia), Shirobhitapa (Headache), Klabiya (erectile dysfunction), Dorbalya (General weakness), and Methunaharsa (Loss of libido). All the symptoms are classified into grades. The improvements in grades were recorded at different levels.

Table 2: Grading of patients with reference to different symptoms:-

Awyakta Darshna/ (Indistinct distance vision)

\begin{tabular}{|l|l|l|}
\hline S.N & & Grading \\
\hline 1 & No feeling of blurring of the vision & 0 \\
\hline 2 & Occasional blurring of the vision & 1 \\
\hline 3 & Routine blurring which affected routine work & 2 \\
\hline 4 & Regular blurring disturbing routine work & 3 \\
\hline 5 & Complete darkness before the eyes & 4 \\
\hline
\end{tabular}


Table 3: Makshikadi abhuta dravya darshan (Floaters)-

Visualization of non-existing objects like flies, gnats, hairs, webs, circles, flags, mirage and ear rings.

\begin{tabular}{|l|l|l|}
\hline S.N & & Grading \\
\hline 1 & No such problem & 0 \\
\hline 2 & Occasional visualization of any such objects & 1 \\
\hline 3 & Irregular visualization of two to four kinds of the above mentioned objects & 2 \\
\hline 4 & Regular visualization of two to four kinds of the above mentioned objects & 3 \\
\hline 5 & Regular visualization of more than four kinds of the above mentioned objects & 4 \\
\hline
\end{tabular}

Table 4: Dwidha Darshana/ (Diplopia)-

\begin{tabular}{|l|l|l|}
\hline S.N & & Grading \\
\hline 1 & No diplopia & 0 \\
\hline 2 & Occasional diplopia & 1 \\
\hline 3 & Regular diplopia without disturbing routine work & 2 \\
\hline 4 & Regular diplopia disturbing day-to-day work & 3 \\
\hline
\end{tabular}

Table 5: Shirobhitapa/ (Headache) - Scored on the frequency of attacks

\begin{tabular}{|l|l|l|}
\hline S.N & & Grading \\
\hline 1 & No headache & 0 \\
\hline 2 & Very occasional headache & 1 \\
\hline 3 & Irregular attacks of frequent headache & 2 \\
\hline 4 & Regular attacks of Headache & 3 \\
\hline
\end{tabular}

Table 6: Vihwala Darshana (Blurred vision)-

\begin{tabular}{|l|l|l|}
\hline S.N & & Grading \\
\hline 1 & Clear vision & $\mathbf{0}$ \\
\hline 2 & Blurred vision on and off (on stimulate) & $\mathbf{1}$ \\
\hline 3 & Blurred vision on and off ( without stimulate) & $\mathbf{2}$ \\
\hline 4 & Always blurred vision & $\mathbf{3}$ \\
\hline
\end{tabular}

Table 7: Erectile dysfunction:

\begin{tabular}{|l|l|l|}
\hline S.N & \multicolumn{1}{|c|}{} & Grading \\
\hline $\mathbf{1}$ & Healthy/No E.D. & $\mathbf{0}$ \\
\hline $\mathbf{2}$ & Some time/Mild E.D. & $\mathbf{1}$ \\
\hline $\mathbf{3}$ & Mostly/Moderate E.D. & $\mathbf{2}$ \\
\hline $\mathbf{4}$ & Completely/Severe E.D. & $\mathbf{3}$ \\
\hline
\end{tabular}

Table 8: Doorbalya (General Weakness)

\begin{tabular}{|l|l|l|}
\hline S.N & & Grading \\
\hline 1 & No weakness & 0 \\
\hline 2 & Mild weakness during hard work. & 1 \\
\hline 3 & Moderate weakness during routine work. & 2 \\
\hline 4 & Excessive weakness during routine work. & 3 \\
\hline
\end{tabular}


Table 9: Methunaharsa (Loss of libido)

\begin{tabular}{|l|l|l|}
\hline S.N & & Grading \\
\hline 1 & No loss libido & 0 \\
\hline 2 & Decreased libido but can perform sexual activity. & 1 \\
\hline 3 & Decreased libido but can perform sexual activity with difficulty. & 2 \\
\hline 4 & Loss of libido and cannot perform sexual activity. & 3 \\
\hline
\end{tabular}

\section{EFFECT OF THERAPY}

The effects of the therapy on 50 patients who had been completed the trial is presented in this section. Subjective parameters i.e. Avyakta Rupa Darshan/ Duram na pashyate (Indistinct distance vision) , Vihwala Darshana (Blurred vision) and Makshikadi abhuta dravya darshan (Floaters) , Dwidha/ Bahuvidha darshan (Diplopia/ Polypia), Shirobhitapa (Headache), Klabiya (erectile dysfunction) ,Dorbalya (General weakness), and Methunaharsa (Loss of libido) improvement were assessed by Wilcoxon matched-pairs signed-ranks test for one group therapeutic effect and for the assessment of therapeutic effect.

Table 10: Effects of Kataka Churna on Avyakta Rupa Darshan (Indistinct distance Vision).

\begin{tabular}{|c|c|c|c|c|c|c|c|c|c|c|}
\hline \multirow{2}{*}{$\mathbf{N}$} & \multicolumn{3}{|c|}{ Mean \pm SD } & \multirow{2}{*}{ \% Change } & \multirow{2}{*}{$\mathrm{T}+$} & \multirow{2}{*}{ T- } & \multirow{2}{*}{ S.E. } & \multirow{2}{*}{ w } & \multirow{2}{*}{$\mathbf{P}$} & \multirow{2}{*}{ Result } \\
\hline & BT & AT & Diff & & & & & & & \\
\hline 50 & 1.76 & $1.52 \pm 0.555$ & 0.24 & $13.64 \%$ & 142.5 & 28.5 & 0.078 & 114.0 & 0.01 & $S$ \\
\hline
\end{tabular}

Table 11: Effect of Kataka Churna on Vihwala Darshana (Blurred Vision) :

\begin{tabular}{|c|c|c|c|c|c|c|c|c|c|c|}
\hline \multirow{2}{*}{ N } & \multicolumn{3}{|c|}{ Mean \pm SD } & \% Change & T+ & T- & S.E. & W & P & Result \\
\cline { 2 - 10 } & BT & AT & Diff & & & & & \\
\hline 50 & 1.84 & $1.70 \pm 0.609$ & 0.14 & $7.60 \%$ & 28.0 & 0.00 & 0.049 & 28 & 0.015 & S \\
\hline
\end{tabular}

Table 12: Effect of Kataka Churna on Makshikadi abhuta dravya darshan (Floaters) :

\begin{tabular}{|c|c|c|c|c|c|c|c|c|c|c|}
\hline \multirow{2}{*}{ N } & \multicolumn{3}{|c|}{ Mean \pm SD } & \multirow{2}{*}{ \% Change } & T+ & T- & S.E. & W & P & Result \\
\cline { 2 - 10 } & BT & AT & Diff & & & & & \\
\hline 50 & 1.78 & $1.66 \pm 0.385$ & 0.120 & $6.75 \%$ & 31.5 & 4.5 & 0.054 & 27 & 0.0547 & IN .S \\
\hline
\end{tabular}

Table 13: Effect of Kataka Churna on Dwidha/ Bahuvidha darshan (Diplopia/ Polypia):

\begin{tabular}{|c|c|c|c|c|c|c|c|c|c|c|}
\hline \multirow{2}{*}{ N } & \multicolumn{3}{|c|}{ Mean \pm SD } & \% Change & T+ & T- & S.E. & W & P & Result \\
\cline { 2 - 10 } & BT & AT & Diff & & & & & \\
\hline 50 & 0.98 & $0.78 \pm 0.519$ & 0.20 & $20.4 \%$ & 111.5 & 24.5 & 0.074 & 87.0 & 0.0547 & S \\
\hline
\end{tabular}




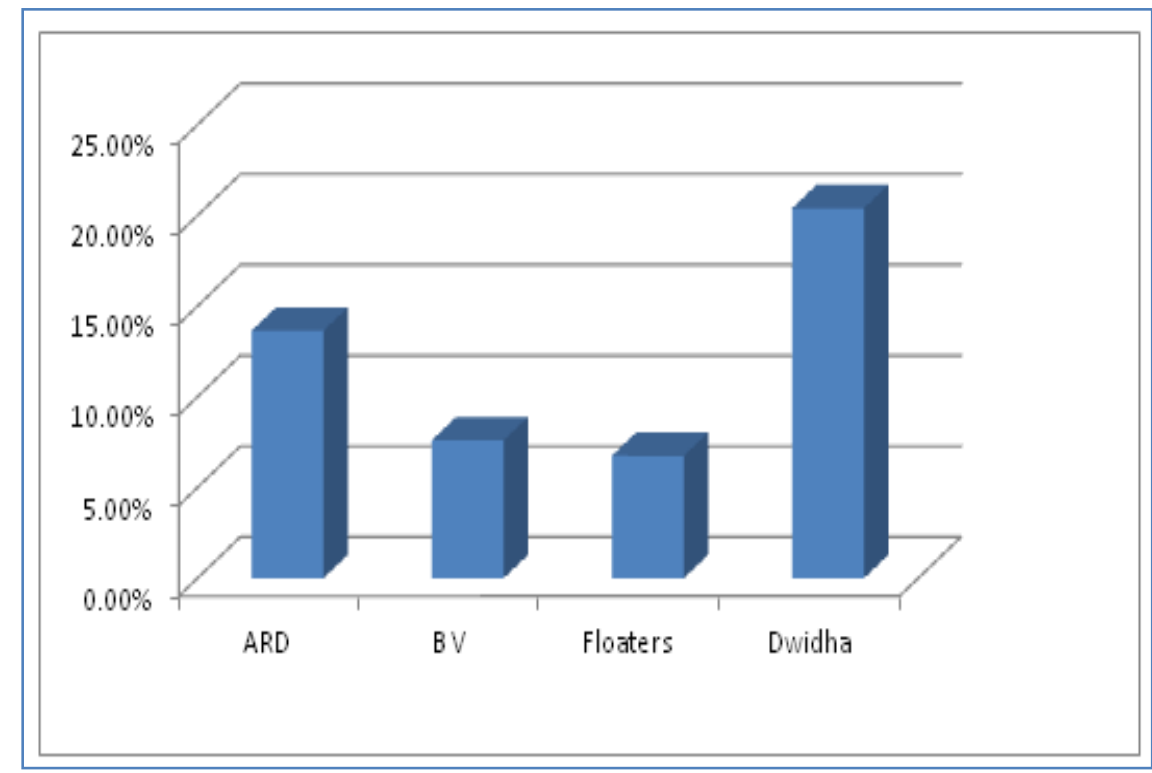

(Symptoms-ARD= Avyakta Rupa Darshan, BV=Blurred vision)

Table 14: Effect of Kataka Churna on Shirobhitapa (Headache) :

\begin{tabular}{|c|c|c|c|c|c|c|c|c|c|c|}
\hline \multirow{2}{*}{ N } & \multicolumn{3}{|c|}{ Mean \pm SD } & \% Change & T+ & T- & S.E. & W & P & Result \\
\cline { 2 - 10 } & BT & AT & Diff & & & & & \\
\hline 50 & 1.84 & $1.70 \pm 0.350$ & 0.14 & $7.61 \%$ & 28.00 & 0.00 & 0.054 & 28.00 & 0.015 & S \\
\hline
\end{tabular}

Table 15: Effect of Kataka Churna therapy on General Weakness:

\begin{tabular}{|c|c|c|c|c|c|c|c|c|c|c|}
\hline \multirow{2}{*}{$\mathbf{N}$} & \multicolumn{3}{|c|}{ Mean \pm SD } & \multirow{2}{*}{ \% Change } & T+ & T- & S.E. & W & P & Result \\
\cline { 2 - 9 } & BT & AT & Diff & & & & & \\
\hline 50 & 1.34 & $1.26 \pm 0.39$ & 0.08 & $5.97 \%$ & 27.0 & 9.00 & 0.05 & 18.0 & 0.015 & IN S. \\
\hline
\end{tabular}

Table 16: Effect of Kataka Churna therapy on Erectile Dysfunction:

\begin{tabular}{|c|c|c|c|c|c|c|c|c|c|c|}
\hline \multirow{2}{*}{ N } & \multicolumn{3}{|c|}{ Mean \pm SD } & \% Change & T+ & T- & S.E. & W & P & Result \\
\cline { 2 - 10 } & BT & AT & Diff & & & & & & \\
\hline 50 & 1.16 & $1.12 \pm 0.44$ & 0.04 & $3.4 \%$ & 33 & 22 & 0.063 & 11 & 0.621 & IN S. \\
\hline
\end{tabular}

Table 17: Effect of Kataka Churna therapy on Loss of Libido:

\begin{tabular}{|c|c|c|c|c|c|c|c|c|c|c|}
\hline \multirow{2}{*}{ N } & \multicolumn{3}{|c|}{ Mean \pm SD } & \multirow{2}{*}{ \% Change } & T+ & T- & S.E. & W & P & Result \\
\cline { 2 - 9 } & BT & AT & Diff & & & & & \\
\hline 50 & 0.86 & $0.78 \pm 0.48$ & 0.08 & $9.30 \%$ & 52.0 & 26 & 0.069 & 26.0 & 0.339 & IN S. \\
\hline
\end{tabular}




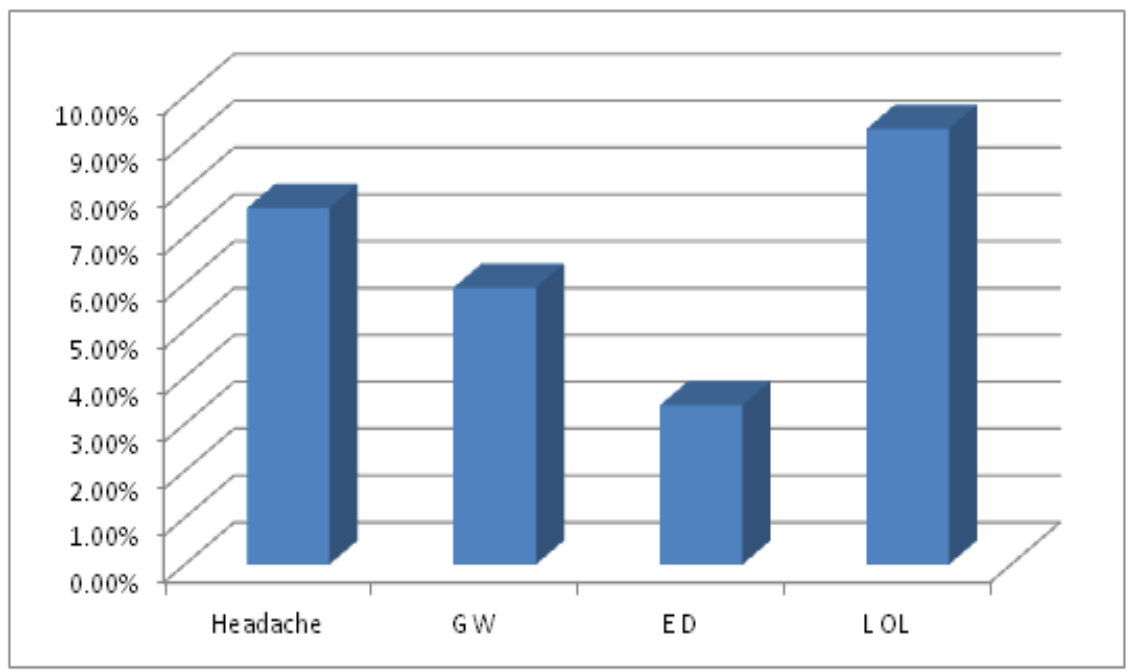

(Symptoms: GE=General Weakness, ED=Erectile dysfunction, LOL=Loss of Libido)

\section{Discussion:}

Various Acharya considered as Chakshuya and many other properities (Vatakaphashamak, water purifier, Vishghana, Kasya. Nertaroga, Ashamari, Madhumeha, Shothpandukamla). ${ }^{\text {ix }}$ $\&^{x}$ Seeds gave alsogavebrucine, strychnine, novacine, icajine, oleanolic acid and its glycoside. The seeds resemble those of Nuxvomica but are non-poisonous.

Properties, which leads to Samprapti Vighatana that control poor vision (Timira) but not male sexual dysfunction. Strychnos potatorum seeds powder possesses suppressive effects on male fertility and could be useful in development of male contraceptive agent. ${ }^{\mathrm{i}}$

The trial drug Kataka churna showed statistically significant results in subjective parameters of Visual disturbances (Timira roga) and visual acuity. However, it showed statistical insignificant results in subjective parameters of male sexual dysfunction (Shukravaha Srotodushthi).

Conclusion: The conclusion of present study is that Kataka churna should not used to treat Male sexual dysfunction.

\section{References}

1. 'Susruta samhita of maharsi-susruta utartantra darsati rag vijanayadhaya -1, sutra13 edited with ayurveda tattva sandipika hindi commentay by kaviraja ambikadutta shastri part 2 chaukhambha sanskrit sansthan varansi.pp-7

2. ii Susruta samhita of maharsi-susruta chikitsya stana chapter -24 , sutra18 edited with Ayurveda tattva sandipika hindi commentay by kaviraja ambikadutta shastri part 2 chaukhambha sanskrit sansthan varansi.pp-132.

3. iiisusruta samhita of maharsi-susruta utartantra chapter -55 , sutra16 edited with Ayurveda tattva sandipika hindi commentay by kaviraja ambikadutta shastri part 2 chaukhambha sanskrit sansthan varansi,pp519.

4. iv Susruta samhita of maharsi-susruta utartantra darsati rag vijanayadhaya -6, sutra-20 edited with ayurveda tattva sandipika hindi commentay by kaviraja ambikadutta shastri part 2 chaukhambha sanskrit sansthan varansi, pp-36.

5. 'Susruta samhita of maharsi-susruta kalp stana chapter-3, sutra 5 edited with ayurveda tattva sandipika hindi commentay by kaviraja ambikadutta shastri part 2 chaukhambha sanskrit sansthan varansi.pp38.

6. ${ }^{\mathrm{vi}}$ Susruta samhita of maharsi-susruta utartantradarsati rag vijanayadhaya -5 , sutra 5,6,7 edited with Ayurveda tattva sandipika hindi commentay by kaviraja ambikadutta shastri part 2 chaukhambha sanskrit sansthan varansi. Pp-29. 
7. vii Susruta samhita of maharsi-susruta utartantradarsati rag vijanayadhaya -1/26 edited with Ayurveda tattva sandipika hindi commentay by kaviraja ambikadutta shastri part 2 chaukhambha sanskrit sansthan varansi. Pp-14

8. viii Sunny E. Ohiaa, Catherine A. Opereb and Angela M. LeDayc, Pharmacological consequences of oxidative stress in ocular tissues., Mutation Research/Fundamental and Molecular Mechanisms of Mutagenesi, Volume 579, Issues 1-2, 11 November 2005, Pages 22-36.

9. Justine R. Smith, Dongseok Choi, Timothy J. Chipps, Yuzhen Pan, David O. Zamora, Michael H. Davies, Bobby Babra, Michael R. Powers, Stephen R. Planck and James T. Rosenbaum, Unique Gene Expression Profiles of Donor-Matched Human Retinal and Choroidal Vascular Endothelial Cells., Invest. Ophthalmol. Vis. Sci. June 2007 vol. 48 no. 6 2676-2684.

10. Rothova A, Suttorp-van Schulten MS, Frits Treffers W, Kijlstra A. Causes and frequency of blindness in patients with intraocular inflammatory disease. $\mathrm{Br} J$ Ophthalmol. 1996;80:332-336.

11. A, Calonge $M$, Pedroza-Seres $M$, et al. Referral patterns of uveitis in a tertiary eye care center. Arch Ophthalmol. 1996;114: 593-599.

12. McCannel CA, Holland $G N$, Helm CJ, et al. Causes of uveitis in the general practice of ophthalmology. UCLA Community-Based Uveitis Study Group. Am J Ophthalmol. 1996;121:35-46.

13. Suhler EB. Incidence and prevalence of uveitis in veterans' affairs medical centers of the Pacific Northwest. Public Health and Preventative Medicine. 2006; Oregon Health \& Science University Portland, OR. Thesis.

14. 'Kaiyadeva-nighantuhaushadvarg suthra1136-1141 edited and translated by Prof.Priyavratasharma and Dr.Guru Prasad sharmaChaukhambhaorientalia -varansi $p$ 211
15. 'Bhavaprakashmisharaprakaranaaamaradiph alvarga Sutra-90 by shriBramashankarSastri of Vidhothinihindi commentary Publisher: Chaukhambasansakrit series office Gopal mandir lean Varansi pp -572

16. ${ }^{\mathrm{xi}}$ Pharmacologyonline 1: 79-83 (2007) Gupta et al. Center for Advanced Studies, Reproduction Physiology Section, Department of Zoology, University of Rajasthan, Jaipur 302002, India ${ }^{\text {xi }}$ 